\title{
Scientists: you really need to get out of the lab more
}

\author{
Paul S Knoepfler
}

There is no rulebook for how to be a scientist-advocate, but that shouldn't stop researchers from engaging with the broader community. In fact, it's an essential part of being a good steward of your science.

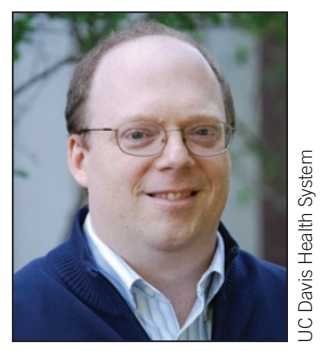

In early July, I received an e-mail informing me that I had won the 2013 National Advocacy Award from the Genetics Policy Institute (GPI), a Florida-based organization dedicated to promoting stem cell research. My first reaction was, "Really? Me?!"

Past winners have been organizations, such as the Alliance for Regenerative Medicine and Research!America, with entire budgets and staffs dedicated to advocacy. The only other individuals honored with GPI's National Advocacy Award were real-estate developer and philanthropist Alfred Taubman, who donated millions of dollars to support stem cell research in Michigan, and the actor Michael J. Fox, a leader in Parkinson's disease research. In contrast, I'm just a stem cell biologist who studies epigenomics and chromatin biology at the University of California-Davis School of Medicine. I'm not an advocate or philanthropist by training or by profession.

Admittedly, however, I have been getting out of the lab more often lately. It started in late 2009, when I was diagnosed with a dangerous form of prostate cancer and underwent surgery to treat it. Soon thereafter, I decided to do things differently. I would still devote my time to research and teaching but, in addition, I would advocate for stem cell research, patient safety and evidence-based medicine. There were no role models of biomedical scientists who were also advocates. Nonetheless, I decided to take the plunge.

I began by blogging about the promise of stem cells and the need for evidence-based medicine. There are no academic grants for blogging, so I forked out $\$ 1,500$ for the domain www.ipscell.com, and I continue to pay about $\$ 500$ per year, out of pocket, to keep the high-traffic website going. Through a combination of hard work-often in the middle of the night and on weekends-and the generous advice of fellow bloggers, most of whom are science writers and tech geeks, I now have one of the most widely read stem cell blogs worldwide. The audience has grown 250-fold in just over three years, catalyzing a rewarding stream of interactions with patients, policy makers and other leaders in the stem cell field, many of whom I have interviewed for the blog-including Nobel laureate John Gurdon and International Society for Stem Cell Research president Janet Rossant.

Beyond the blog, I have also found myself driven to advocacy in other ways. Last year, it occurred to me that the stem cell field needed different kinds of awards-ones that rewarded risk taking and outside-the-box thinking. I sponsored a contest for short essays about stem cells, with a category for adults and one for youth, and I bought two \$50 iTunes gift cards as prizes. One went to an undergraduate student who wrote about the possibility of a stem cell supercomputer; the other to a middleschool student who considered how regenerative medicine could affect notions of 'self'.

Next, I created the Stem Cell Person of the Year Award. My readers submitted 30 nominations, which I pared down to 16 finalists. I then used an Internet survey to guide my decision for a winner. In the end, 4,655 votes were cast, more than 1,000 of them for the person who ended up being the voters' (and my) top pick: Roman Reed, a strong advocate of spinal-injury research who last year helped catalyze the TJ Atchison
Spinal Cord Injury Research Act in Alabama. Call me crazy, but I wrote Reed a $\$ 1,000$ check for the prize out of my personal bank account. I now plan to give the award on an annual basis.

I also decided last year to create a basic fact page about stem cells, which has since been translated into 28 languages, and to write a book about stem cells. My goals were to target an educated lay audience, give my own opinions together with facts and cover all the most important and controversial topics in the field. The result was Stem Cells: An Insider's Guide, which comes out this month. I do not expect to make much (if any) money from this book, and I have not received any major philanthropic gifts for my advocacy; rather, I advocate because I find making a difference to be fulfilling.

To all this a reader might say, "Okay, this all sounds well and good, but you can't have your cake and eat it, too! Your science must have suffered from all this." In fact, I have lost some sleep, but I have not seen much in the way of negative scientific consequences. My lab has done very well during the past three years, and we have published many important papers, including one earlier this year that demonstrated the molecular similarities between induced pluripotency in stem cells and oncogenic transformation in cancer cells ${ }^{1}$. I even secured tenure during this time.

Reflecting on my personal transformation to the role of scientistadvocate, I have come to notice many tangible positive outcomes. In a general sense, my work has served to build bridges and stimulate new dialogue between industry and academia in the stem cell field. At the same time, I couple these efforts to accountability. Today, if someone does an Internet search for 'stem cell blog', that person will find my site, with all its educational outreach resources, at the top of the results list. A few years ago, the same search would mostly have yielded sites published by opponents of stem cell research or proponents of sketchy, for-profit endeavors to attract stem cell 'tourism'. I have also interacted with more than 100 patients and caregivers, helping them make more educated and, I believe, safer, stem cell-related medical decisions with their physicians.

I do not claim any particular gift for public outreach or special knowledge of the Internet that has made me uniquely able to advocate. Any scientist can, and should, do it. It is only logical that scientists would adapt to today's reality-a funding-poor environment that is nonetheless rich with opportunities for communication-by becoming advocates. I predict that any scientist who devotes a tiny bit of time to advocacy endeavors will find that the payoff is greatly multiplied. I will even help. Drop me an e-mail. Or better yet, leave a comment on my blog or message me on Twitter. Let's get the conversation going.

Paul S. Knoepfler is an associate professor in the School of Medicine of the University of California, Davis, California, USA, and the author of Stem Cells: An Insider's Guide, published this month by World Scientific. He blogs at http://www.ipscell.com and can be found on Twitter@pknoepfler. e-mail: knoepfler@ucdavis.edu

1. Riggs, J.W. et al. Stem Cells Dev. 22, 37-50 (2013). 